\title{
Current Status of the Clinical Development of Gene Therapy
}

\author{
Sun-Il Kwon ${ }^{\dagger}, *$ \\ Department of Biomedical Laboratory Science, Deagu Health Science University, Daegu 41453, Korea
}

The concept of gene therapy is to treat a disease by transferring therapeutic nucleic acids to a patient's cells. It took several decades from the basic theoretical proposal of gene therapy to the current promising treatment option for some important human diseases. The encountered adverse effects in the early clinical studies boosted the development of sophisticated vectors and elaborate clinical designs. The gene therapy is now considered to have the potential to cure many diseases that are incurable with conventional medications. By the end of 2017, about 2,600 clinical trials of gene therapy have been performed or are ongoing for a variety of diseases such as cancers, monogenic diseases, cardiovascular diseases and neurological diseases etc. Here, we present a brief introduction of technical achievement in relation to gene therapy development, and a review of the current status of global gene therapy clinical development.

Key Words: Gene therapy, Cancer, Clinical study, Vector, Target diseases, Guidelines

\section{서 론}

유전자치료는 질병을 치료하기 위하여 핵산을 환자의 세포 내로 투여하는 치료방법이다. 종래의 치료방법은 질 병이 발생한 후 물리적으로 원인을 제거하거나 화합물을 투여하여 질병의 원인 물질을 억제하는 방법이 주가 되었 는데 반하여, 유전자치료는 환자의 유전자 자체를 변형시 켜서 질병의 원인을 제거하거나 비정상 유전자가 제 기능 을 하도록 돕는 치료방법이다. 즉 유전자로 인하여 발생된 질병의 경우에 유전적인 원인 그 자체를 제어하는 방법 이다.

유전자치료는 현재로서 마땅한 치료방법이 없는 수많은 난치성질환을 유전자 수준에서 근본적으로 치료할 수 있 는 차세대 치료기술이다. 유전자치료법의 대상이 되고 있 는 병은 거의 모든 종류의 암, 혈우병 등의 유전성질환,
$\mathrm{AIDS}$ 등의 감염성질환, 심혈관계질환 등으로 다양하다. 상당한 부가가치를 창출할 수 있는 첨단기술로서 적용범위 가 넓어서 세계적으로 비상한 관심을 끌고 있는 분야이다. 유전자치료는 21 세기를 통하여 열릴 분자의학시대에 세 포치료법과 함께 중심적이고 궁극적인 치료방법으로 자리 를 잡을 것으로 전망된다. 지난 30 여년 간 노력의 결실로 최근 수년 동안 여러 개의 유망한 유전자치료제가 승인되 어 출시되기 시작했다. 현재 세계 도처에서 중요한 유전 자치료제 연구가 진행되고 있으며, 조만간 유전자치료 시 대가 본격적으로 개화될 것으로 전망된다. 본고에서는 유 전자치료제 연구의 현황과 동향을 고찰해보고자 한다.

\section{유전자치료제 개발의 기술적 기반}

\section{유전자치료제의 정의}

유전자치료는 비정상 돌연변이 유전자를 정상 유전자로

Received: July 10, 2018 / Revised: September 3, 2018 / Accepted: September 4, 2018

*Professor.

${ }^{\dagger}$ Corresponding author: Sun-Il Kwon. Department of Biomedical Laboratory Science, Deagu Health Science University, Youngsong-ro 15 (Taejeon-dong), Buk-ku, Daegu 41453, Korea.

Tel: +82-53-320-1870, Fax:+82-53-320-1450, e-mail: psikwon@dhc.ac.kr

(C) The Korean Society for Biomedical Laboratory Sciences. All rights reserved.

(9) This is an Open Access article distributed under the terms of the Creative Commons Attribution Non-Commercial License (http://creativecommons.org/licenses/by-nc/3.0/) which permits unrestricted non-commercial use, distribution, and reproduction in any medium, provided the original work is properly cited. 
대체시켜서 유전적 결함을 치료하는 방법이다. 넓게 보면 환자의 유전체 구성에 변화를 주어 유전적 결함을 교정하 는 모든 치료행위를 유전자치료로 간주할 수 있다.

유전자로 치료하는 유전자치료제의 정의는 각국의 규제 기관마다 각기 다른 사정에 따라서 정해져서 서로 조금씩 다르다. 우리나라는 '생물학적제제 등의 품목허가 심사규 정' 제 2 조에 따라 "질병치료 등을 목적으로 인체에 투입되 는 유전물질 또는 유전물질을 포함하고 있는 의약품"으로 규정하고 있다. 미국 FDA의 경우에는 Guidance for Human Somatic Cell Therapy and Gene Therapy (Mar, 1998)에서 유 전자치료를 정의하고 있다. 이 Guidance의 'Definition of somatic cell therapy and gene therapy' 부분에서 "유전자치료 는 살아있는 세포에 유전물질을 도입하는데 기초한 의료 기술로서, 세포를 체외에서 조작하여 인체로 투여하거나 유전자를 생체 내로 직접투여하여 유전자를 치료한다. 체 외에서 세포의 유전자를 조작하여 환자에게 투여하는 경 우 체세포치료의 한 형태가 된다. 유전자조작은 치료, 예 방 또는 특정 세포의 사후 추적을 위하여 수행된다".라고 정의되어 있다(Ser et al., 2015).

유럽 의약품감독국(European Medicines Agency, EMA)에 서는 유전자치료제를 "(a) 유전자 서열을 조절, 수정, 대체, 추가, 또는 소실시키기 위하여 인체에 투여되는 재조합 핵 산을 활성성분으로 함유하는 것으로, (b) 유전자치료제의 치료, 예방 또는 진단효과는 재조합 핵산 서열에 의하거 나 이 서열의 유전적 발현 산물에 의한 것이다"라고 정의 한다(Part IV of Annex I to Directive 2001/83/EC) (Seo et al., 2015).

\section{유전자치료제 개발의 접근 방식}

유전자치료는 질환의 근본원인을 분자수준에서 규명하 여 치료하므로 대증요법이 아닌 근원적인 치료가 가능해 진다. 다른 치료제가 표적화하기 힘든 표적도 질병의 기 전을 알고, 원인 유전자를 정확히 파악하면 표적화가 가 능하기 때문에 난치병의 치료에 최적이라 할 수 있다.

유전자치료에서는 두 가지 접근 방식이 있는데 결함 유 전자를 정상 유전자로 대체하거나, 결함 유전자를 무력화 (disruption)시키는 방법이다. 치료용 DNA는 투여된 후 목 표하는 세포에 도달하여야 하고, 세포 내에 들어가서 자 신이 직접 발현되거나, 혹은 결함 유전자의 발현을 저해 하여야 한다. 유전자의 전달을 위해서는 재조합 바이러스 나 naked DNA 등이 사용된다.

\section{Ex vivo 유전자 전달 vs. in vivo 유전자 전달}

유전자치료제는 유전자가 세포 내로 전달되는 위치에 따라서 ex vivo 치료제와 in vivo 치료제로 나누어진다. $E x$ vivo 유전자치료제의 경우 체외에서 유전자를 특정 세포에 도입하여 증식시킨 후에 이 세포(gene-modified cells)를 환 자의 체내로 투여한다. 줄기세포, $\mathrm{T}$-세포, 연골세포, 수지상 세포 등이 체외 유전자 도입을 위하여 사용된다. 이 방법 은 목표 이외의 장기나 조직이 무작위 하게 반응하여 생 기는 off target 효과를 줄일 수 있는 장점이 있다. 또한 바 이러스 벡터를 직접 체내에 주입할 때 생기는 면역반응도 최소화시킬 수 있다. 주입 전에 형질전환 세포의 기능 평 가가 가능하기 때문에 품질관리와 효능확보가 용이하다 (Lee, 2016).

In vivo 치료제의 경우 전하고자 하는 유전자를 플라스 미드나 바이러스 등의 벡터에 넣은 후 이 벡터를 환자에 게 투여하는 방식이다. 이 방법은 세포의 추출, 형질전환, 배양 등의 체외조작이 필요 없기 때문에 제제의 준비에 시간과 비용을 줄일 수 있다. 그러나 직접투여로 인하여 off target 효과가 발생할 가능성이 존재하고 유전자 운반 체 바이러스 자체가 면역반응을 유발하여 부작용이 발생 할 수 있다. 유발된 면역반응은 치료효과를 감소시킬 수 도 있다.

Ex vivo 방식이든 in vivo 방식이든 유전자치료제의 유효 성이 확보되려면 유전자가 세포 내로 전달되고 또 적절히 발현되어야 하므로, 유전자 전달체 기술은 유전자치료제 개발에서 가장 핵심적인 기술 중의 하나이다(Seo et al., 2015; Lee, 2016).

\section{유전자치료의 대상이 되는 세포}

체세포 유전자치료는 생식과 분화와 관련이 있는 생식 세포, 배우자세포, 미분화줄기세포를 제외한 다른 세포로 유전자를 전달한다. 따라서 유전적 변화는 환자 개인에게 만 국한되고 후손에게 유전되지 않는다. 이에 따라 DNA 를 이용하여 질병을 치료하고자 할 때, 체세포 유전자치 료 방법은 기초연구나 임상연구 모두에서 거의 대부분을 차지한다.

생식세포 유전자치료는 기능적인 유전자를 생식세포에 도입하여 유전적인 변형(modification)을 가하는 일이다. 따 라서 초래되는 유전적인 변화는 후손에게 전달된다. 대부 분의 국가에서는 생식세포 유전자치료 연구를 금지하고 있다. 그러나 인간의 유전자 변형에 대한 구체적인 제한 
이 없는 국가도 있다.

\section{유전자 전달기술 - 벡터(vector)}

유전자 전달기술은 크게 3가지인데 물리적, 화학적, 생 물학적 전달기술로 구분된다.

첫째, 물리적인 방법에서는 유전자를 바이러스처럼 다 른 전달체가 없이 플라스미드 단독 상태(naked plasmid)로 투여한다. 유전물질을 세포 내로 투입하기 위하여 전기천 공법(electroporation)을 사용하기도 하는데, 전기적 자극으 로 세포막에 일시적으로 구멍을 뚫어서 유전자를 전달한 다. 그 외에 유전자총(gene gun), 초음파천공법(sonoporation), 자기장 이용 주입(magnetofaction)과 같은 방법을 사 용하기도 한다.

둘째, 화학적인 기술은 리포솜과 같은 고분자를 이용하 여 유전자를 감싸고, 이를 생체 내에 투여하여 세포의 탐 식작용(endocytosis)으로 세포 내에 도달시키는 기술이다. 지질소재를 전달체로 사용하는 lipofection 방법이 흔히 사 용되고 있다.

물리적, 화학적 방법과 같은 비바이러스성 벡터는 바이 러스가 체내로 유입되지 않으므로 면역반응으로 인한 피 해가 적고, 생산과정이 비교적 간단하여 낮은 비용으로 대량생산이 가능하다는 장점을 가진다. 그러나 비바이러 스성 벡터는 유전자전달 효율이 낮고 발현이 일시적이라 는 것이 단점으로 지적되어 바이러스 벡터를 많이 사용한 다(Lee, 2016). 비바이러스성 유전자전달 방법으로 가장 많이 사용되는 것은 naked plasmid (naked DNA)이다. 이 방 법은 조직에 바로 DNA를 투여하여 유전자가 발현되도록 한다. 바이러스 벡터에 비하여 유전자 발현 정도가 낮으 며 투여가 가능한 부위도 제한적이다.

세 번째인 생물학적인 방법은 바이러스를 이용하는데 바이러스에 원하는 유전자를 삽입하여 유전자 재조합 바 이러스를 만들고 이를 생체 내로 투여하는 방식이다(Seo et al., 2015). 바이러스는 자신이 가진 감염성 덕분에 숙주 세포 내로 용이하게 침투한다. 숙주세포 내로 침투한 후, 감싸고 있던 외피를 벗고 유전물질을 세포 내로 방출하 고 유전자를 발현시킨다. 이러한 바이러스의 성질을 이용 하는 것이 바이러스 벡터이다. 벡터로 사용되는 대표적인 바이러스로는 아데노바이러스(adenovirus), 아데노연관바이 러스(adeno-associated virus (AAV)), 헤르페스바이러스(herpes simplex virus (HSV)), 렌티바이러스(lentivirus), 백시니아바 이러스(vaccinia virus) 등이 있다. 벡터용으로 사용되는 바 이러스는 대부분 병원성이 제거되고, 세포 내에서 자가
복제가 불가능하도록 제작된 것들이다.

아데노바이러스는 지금까지 가장 많이 사용되는 바이러 스이다. 아데노바이러스는 병독성이 강한 바이러스로서 고열을 동반하는 목감기와 인후편도염, 유행성 각결막염, 출혈성 방광염 등을 일으킨다. 벡터로 사용되는 아데노바 이러스는 $\mathrm{Ad} 2, \mathrm{Ad} 5$ 가 대표적이다. 전달효율이 좋고 분열 혹은 미분열세포에 이용이 가능하다. 면역반응 유도가 문 제가 되었으나 $\mathrm{E} 2 \mathrm{~B}$ 와 같은 면역반응 관련인자를 제거하 는 노력으로 많이 개선되었다. 여러 가지 종류의 암, 협심 증, 관상동맥질환 등의 임상연구에 사용되고 있다.

아데노연관바이러스(AAV)는 작은 바이러스로 인간을 감염시키지만, 면역반응을 매우 약하게 일으키며 질병을 유발하지 않는다. 유전자치료 벡터로서 $\mathrm{AAV}$ 는 분열세포, 미분열세포 모두를 감염시키며 숙주게놈에 함입되지 않은 채로 지속되는데, 함입될 경우에도 특정한 장소에만 들어 가서 예측이 가능하다. 이러한 특성으로 $\mathrm{AAV}$ 는 유전자치 료의 좋은 벡터 후보가 되었다. 한 가지 단점은 유전체가 $4.8 \mathrm{~kb}$ 로 작아서 치료용 유전자를 넣기 위해서는 두 유전 체를 연결한 concatemer를 만드는 등의 조작이 필요하다. 임상시험 대상질환으로는 레버선천성 흑암시, 파킨슨병, 혈우병 $\mathrm{B}$, 알츠하이머, 낭포성섬유증, 만성폐쇄성질환 등 다수가 있다.

레트로바이러스는 유전자치료제 연구에 초창기부터 사 용되었다. 레트로바이러스는 항원성이 낮고, 장기간 발현 시키는 장점이 있으나, 유전물질을 숙주 유전체에 무작위 로 아무 위치에나 삽입시키는 문제가 있다. 유전자의 가 운데에 삽입될 경우에는 유전자 기능을 상실시킬 수 있고, 특정 유전자의 조절부위에 삽입될 경우 암을 유발할 수 도 있다. $\mathrm{ADA}$ 결핍증, 관절염, $\mathrm{HIV}$ 감염, 피부암, 난소암, 림프종 등의 임상연구에 사용되었다.

폭스바이러스(Poxvirus) 벡터인 MVA (modified vaccinia virus Ankara)도 사이토카인이나 암 관련 항원을 탑재하여 폐암이나, 대장암 치료에 임상시험을 진행 중이다. 렌티바 이러스 벡터도 암항원 유전자를 탑재하여 폐암, 난소암 등의 환자를 대상으로 임상시험을 진행하고 있다.

다른 종류의 바이러스로는 암치료에 사용되는 암용해 (oncolytic) 바이러스가 있다. 이 용도의 바이러스는 유전자 전달 목적 이외에도 암세포를 감염시켜서 직접적으로 암 세포를 사멸시키고, 그 다음 암세포의 항원을 노출시켜서 환자의 면역세포를 활성화시킨다. 암용해 바이러스는 암 세포에서만 증식이 가능하도록 조작되어 있어서 암세포를 선택적으로 사멸시킨다. 잘 알려진 암용해 바이러스로는 
2015년 미국 FDA 승인을 획득한 흑색종 치료제인 암젠 (Amgen)의 임리직(Imlygic)이 있는데 헤르페스바이러스를 약독화시켜서 만든 것이다. 이 암용해 바이러스들은 암세 포를 골라서 살상시키고, 살상된 암세포 내의 암항원을 외부에 노출시켜서 면역세포를 유도, 활성화시킴으로 복 합적인 항암효과를 발휘한다. 국내에서 개발된 신라젠의 펙사벡(Pexa-Vec)도 암용해 바이러스인데 간암환자를 대 상으로 글로벌 임상 3 상을 진행 중이다. 캐나다의 온코리 틱 바이오텍(Oncolytics Biotech, Inc.)의 레오리신(Reolysin) 은 췌장암, 난소암 등 여러 암종을 대상으로 임상시험을 하고 있다. 다른 후보로는 호주의 비라리틱스사(Viralytics Ltd.)가 콕사키바이러스(Coxackievirus)인 카바택(Cavatak) 을 미국 디엔에이트릭스사(DNAtrix, Inc.)가 아데노바이러 스인 DNX-2401을 임상시험 중이다(Choi, 2017).

\section{유전자치료제의 임상개발과 시판 승인}

유전적인 결함을 지닌 사람에게 외부의 정상 유전자를 넣어서 치료하자는 유전자치료는 1972년도에 Friedmann과 Robin이 처음으로 구체적으로 제안하였다고 볼 수 있다 (Friedmann and Robin, 1972).

유전자치료에 대한 임상연구는 1990년에 들어와서 처음 으로 승인되었다. 대상환자는 네 살의 Ashanti DeSilva로 희귀질환인 Adenosine Deaminase (ADA) 결핍 중증복합면 역결핍증(ADA-SCID)으로 $\mathrm{ADA}$ 효소가 결핍되어 심각한 면역체계결핍을 겪고 있었다. 이 질환은 면역기능의 저하 로 무균 bag에서 살아가야 하기 때문에 bubble-bag disease 라고도 불린다. 이 환자로부터 백혈구를 채취한 후, 정상 $\mathrm{ADA}$ 유전자를 삽입하고, 이 세포로부터 $\mathrm{ADA}$ 활성 생성 을 확인한 후에 환자에게 되돌려주었다. 이 과정을 반복 한 후에 환자의 면역체계는 bubble bag이 필요 없을 정도 로 회복되었다(Blaese et al., 1995).

유전자치료제 연구는 바이러스를 유전자 전달체로 사용 하면서 희귀유전병 분야에서부터 먼저 시작되었지만 암을 비롯한 다른 질환으로 대상이 확장되었다. 1993년 다형성 교아종(glioblastoma multiforme) 환자를 대상으로 인슐린유 사성장인자 안티센스 RNA를 이용한 임상시험이 수행되 었다(Trojan et al., 1993).

1992년에는 ADA-SCID 임상시험을 받던 피험자 어린이 10 명 중 2 명에게서 백혈병 유사증상이 나타나서 임상시 험이 일시적으로 중단되는 일이 발생하기도 했다. 1999년 에는 18세의 Jesse Gelsinger가 ornithine transcarbamylase
결핍증 유전자치료를 받다가 숨지는 사고가 발생하여, 미 국 $\mathrm{FDA}$ 는 임상시험을 중단 조치하였다. 이 환자는 정상 유전자를 가지는 아데노바이러스 벡터를 주입받은 후 4일 만에 바이러스로 인한 과도한 면역반응 때문에 사망하였다. 2000년 3월에는 관상동맥질환을 치료하기 위하여 vascular endothelium growth factor-2 (VEGF2)를 투여하는 임상시험 에서 사지혈관 통증의 문제가 발생하여 다시 FDA에서 임 상시험 중단이 결정되었다. 이때는 바이러스가 아닌 비교 적 안전하다고 여겨진 naked plasmid 형태로 유전자를 혈 관투여로 전달하였었다. 이러한 일로 인하여 유전자치료 는 아직 이르다는 부정적인 기류가 일시적으로 형성되었 고, 미국 $\mathrm{FDA}$ 는 유전자치료에 대해서 윤리와 절차에 대 하여 신중하게 재평가를 하게 되었다. 초기에 아데노바이 러스 벡터를 사용한 임상시험에서 부작용이 일어나기도 했지만 이후에 렌티바이러스 벡터, $\mathrm{AAV}$ 벡터가 개발되면 서 효능과 안전성이 향상되었다. 또한 적절한 임상디자인 과 더불어 유전자치료에 적합한 질환이 선정되면서 유전 자치료 연구는 다시 활발해졌다.

2002년 쥐실험에서 낫세포빈혈증(Sickle cell disease)이 유전자치료로 치료됨이 입증되었다. 돌연변이 $\mathrm{HbS}$ 의 중합 을 막는 betaA globin 유전자를 렌티바이러스에 넣은 다음, 쥐 성체 적혈구세포에서 발현시켰는데, 낫적혈구의 형성 이 억제되는 것이 명백하게 나타났다(Pawliuk et al., 2001).

임상시험적 시도에서 더 나아가 유전자치료제로서 시판 될 수 있는 세계 최초의 상용화된 유전자치료제는 중국에 서 등장하였다. 중국 보건당국은 2003년에 아데노바이러 스를 기반으로 한 두경부암 치료제로 Gendicine을 승인하 였고, 2005년에는 암용해 바이러스인 Oncorine을 비인두암 치료제로 승인하였다. 다른 유전자치료제로는 2004년에 라트비아에서 ECHO-7 virus를 기반으로 한 흑색종 치료제 RIGVIR가 승인되었고, 2007년에 필리핀에서 retrovirus 기 반의 유방암, 췌장암 바이러스 치료제 Rexin-G가 승인되 었다. 그리고 2011년에 러시아에서 plasmid VEGF 기반의 말초동맥질환치료제 Neovasculgen이 허가되었다. 그러나 이 제품들은 글로벌 치료제로 인정받지 못하고 모두 자국 내에서만 한정적으로 사용되었다(Seo et al., 2015).

글로벌 기준을 충족하는 서방세계 최초의 상용화된 유전자치료제는 2012년 네덜란드에서 허가된 글리베라 (Glybera, alipogene tiparvovec)라고 할 수 있다. 글리베라는 지단백 지질분해효소(lipoprotein lipase (LPL)) 유전자를 가 진 아데노연관바이러스(adeno-associoated virus, $\mathrm{AAV}$ )를 기 반으로 한다. 글리베라는 가족성 LPL 결핍증으로 지방분 
해를 못하는 환자에게 AAV1 벡터를 이용해서 근육에 LPL 유전자를 직접 전달한다(Scott, 2015).

2015년에는 미국의 암젠사(Amgen)가 악성피부암인 악성 흑색종을 치료하는 임리직(Imlygic, talimogene laherparepvec 혹은 'T-vec')으로 미국 FDA에서 허가를 받았다. 임리직은 herpes simplex virus type 1 을 이용하여 암세포를 사멸시키 는 암용해 바이러스 개념의 치료제이다. 이 암용해 바이 러스는 암세포 내에서 복제되어 방출되면서 암세포를 터 트려서 사멸시킨다(Conry et al., 2018).

2016년에는 스트림벨리스(Strimvelis)와 스핀라자(Spinraza, nusinersen)가 승인되었다. 글락소스미스클라인사(GSK) 의 스트림벨리스는 ADA-SCID 환자의 치료를 위해 유럽 European Medicines Agency (EMA)에서 승인을 받았다. 환 자 본인의 줄기세포(CD34+ 조혈모세포) 일부를 분리해 내고 바이러스 벡터를 이용해 건강한 $\mathrm{ADA}$ 유전자의 copy 를 이 줄기세포에 삽입하였다. 이어서 정상적인 $\mathrm{ADA}$ 가 발현되는 줄기세포를 환자에게 되돌려주는 과정을 거쳤다. 이 방식은 세포를 기반으로 한 환자 개인에 대한 맞춤형 치료이다(Stirnadel-Farrant et al., 2018).

스핀라자는 미국 아이오니스파마슈티컬즈(Ionis Pharmaceuticals)가 개발했는데 2016년 12월 미국 FDA에서 척수 성 근위축증(Spinal Muscular Atrophy (SMA)) 치료제로 승 인을 획득하였다. 세계 최초의 RNA 치료제로 기록되는데 기존 치료제가 접근하기 힘든 pre-mRNA를 겨냥한다. 척 수성 근위축증 환자는 $\mathrm{SMN1}$ 유전자의 돌연변이나 결실 로 인하여, 운동신경세포의 건강과 기능을 유지하는 $\mathrm{SMN}$ 단백질(생존 운동신경세포 단백질)을 충분히 생산하지 못 한다. SMN2 유전자는 SMN1 유전자의 백업 역할을 하지 만, SMN2 유전자의 SMN 단백질 생산량은 $10 \%$ 에 불과하 여 부족하다. 스핀라자는 SMN2 유전자 pre-mRNA의 인트 론 7의 ISS-N1 위치에 결합하여 full length SMN2 mRNA 를 생성하도록 유도하여 $\mathrm{SMN}$ 단백질의 생산량을 증가시 킨다(Lee, 2017a; Paton, 2017; Spinraza homepage, 2018).

2017년에는 3종의 유전자치료제가 미국 FDA의 승인을 받았다.

노바티스사(Novartis)의 킴리아(Kymriah, tisagenlecleucel) 는 세계 최초의 키메라 항원 수용체 $\mathrm{T}$ 세포 치료제(Chimeric antigen receptor T cell (CAR-T))로 미국 FDA에서 2017년 8월 승인을 받았다. 킴리아는 환자의 $\mathrm{T}$ 세포를 채 취한 뒤에, 표면에 CD19 항원을 가진 백혈병세포를 표적 으로 삼고 사멸시키도록 한 키메라 항원 수용체 단백질을 발현하는 유전자를 $\mathrm{T}$ 세포에 도입한 후에, 이를 다시 환자
에게 주입하면 이 세포가 암세포를 공격하는 원리이다. 이 와 같이 CAR-T는 환자 맞춤형 치료제다. 킴리아는 불응 성이거나 최소 2 번 이상 재발한 25 세 이하의 $\mathrm{B}$ 세포 전구 급성 림프구성 백혈병 환자를 위한 치료제로 승인되었다. 노바티스는 킴리아를 성인 재발성 또는 불응성 미만성 거대 $\mathrm{B}$ 세포 림프종 등에 대한 추가적 승인을 진행 중이 다. 가장 흔한 부작용은 사이토카인 방출 증후군(cytokine release syndrome)인데, 약 절반의 환자들에게서 나타났으나 증상이 일시적이었고 치료가 가능했다(Lee, 2017b; Liu et al., 2017).

길리어드사(Gilead Science)에 의해 인수된 카이트파마 (Kite Pharma)의 예스카타(Yescarta, axicabtagene ciloleucel)가 미국 FDA에서 2017년 8월 승인되었는데 CAR-T 치료제 로서 두 번째이다. 에스카타는 환자의 $\mathrm{T}$ 세포를 체외에서 유전자조작하여 CD28과 CD3-zeta co-stimulatory domains가 연결된 anti-CD19 CAR T-세포로 만든다. 이 세포는 다시 환자에게 투여되면 $\mathrm{CD} 19$ 를 발현하는 표적 암세포를 인식 하고 제거한다. Anti-CD19 CAR T-세포가 CD19를 발현하는 표적 암세포와 결합되면 CD28과 CD3-zeta co-stimulatory domains가 하류의 신호전달연쇄를 활성화시킨다. 그러면 $\mathrm{T}$ 세포가 활성화되고 증식되며, 사이토카인을 방출하면서 $\mathrm{CD} 19$ 를 발현하는 세포를 죽이게 된다. 예스카타는 전신 요법을 받은 상태인 미만성 거대 $\mathrm{B}$ 세포 림프종(DLBCL), 원발성 종격동 거대 $\mathrm{B}$ 세포 림프종 $(\mathrm{PMBCL})$, 고등급 $\mathrm{B}$ 세포 림프종, 소포림프종에서 DLBCL로 전환된 변형된 소 포림프종(TFL)을 비롯한 재발성 또는 불응성 거대 $\mathrm{B}$ 세 포 림프종을 않는 성인 환자를 대상으로 한 치료제로 승 인되었(Roberts et al., 2017).

스파크 세라퓨틱스(Spark Therapeutics)사의 럭스터나 (Luxturna, voretigene neparvovec-rzyl)가 2017년 12월 유전 자치료제로 미국 FDA에서 승인됐다. 럭스터나는 이중대 립유전자성(biallelic) RPE65 돌연변이와 연관된 망막디스 트로피(retinal dystrophy)를 않는 환자를 대상으로 단회투 여하는 유전자치료제이다. RPE65 유전자는 정상적인 시 력을 위해 필요한 효소를 코딩하는데 돌연변이 시 효소의 활성이 감소하거나 결여돼 시력손상이 일어난다. 럭스터 나는 정상 PE65 유전자를 아데노연관바이러스 벡터를 이 용하여 망막세포에 직접 전달하여 부족한 유전자를 보충 해주도록 한다. 럭스터나는 RPE65 유전자 카피 2개의 변 이가 확인됐으며 살아있는 망막세포가 충분한 환자에게 만 투여할 수 있다. 럭스터나는 FDA로부터 혁신치료제, 희귀의약품으로 우선검토 대상으로 지정받았다. 또한 희 
귀소아질환 예방 및 치료를 위한 의약품 개발을 장려하는 프로그램 하에 희귀소아질환 우선검토 바우처를 받아서 신속하게 승인 검토를 받을 수 있었다(Lee, 2017c; Ameri, 2018).

여러 가지 유전자치료제가 이렇게 미국과 유럽에서 잇 달아 승인되면서 유전자치료제의 연구 개발이 세계적으로 확대되어가고 있다. 유전자치료제 개발은 이제 안정권에 들어서 확장 국면에 들어섰다고 평가되고 있다.

\section{유전자치료제의 임상개발 현황}

\section{유전자치료 관련 학술문헌 건수(2010-2017)}

유전자치료제의 개발과 관련된 학술문헌 건수는 PubMed (PubMed, 2018)를 이용하여 분석하였다. PubMed의 advanced search를 이용하여 검색어 gene therapy [all field] 로 연도별로 나누어 2010년부터 2017년까지 검색하였다. 2010년 18,161건에서 2016년 28,225건으로 유전자치료제 관련 문헌 수가 년간 약 1,000 에서 2,000 여건 정도로 꾸 준히 증가하였다. 논문수의 증가 추세를 볼 때 유전자치 료제 분야의 연구 개발이 꾸준히 지속적으로 성장하고 있 는 것으로 보인다.

\section{유전자치료제의 임상시험 승인 건수(1989-2017)}

The Journal of Gene Medicine에서는 세계적으로 허가되거 나, 진행 중이거나, 완료된 임상시험 숫자를 집계하여 세 계 유전자치료 임상 현황 자료(Gene Therapy Clinical Trials Worldwide)를 발표하고 있다(Gene Therapy Clinical Trials Worldwide homepage, 2018). 1989년 처음 유전자치료제 임 상시험이 승인된 이래로 2017년 11월까지 총 2,597건의 임상시험이 승인되었다. 2000 년대에 들어서 연간 약 100 건 정도의 새로운 유전자치료제 임상시험이 승인되어지고 있 으며, 2015년에는 169건, 2016년에는 118건, 2017년에는 132건의 유전자치료제 임상연구가 세계적으로 승인되었다. 임상시험이 승인된 유전자치료제 data는 임상시험이 수행 된 대륙과 국가, 목표하는 적응증, 사용된 유전자 운반체, 전달된 유전자형, 임상시험 단계, 허가 및 개시된 임상시 험 건수(1989년-2017년)와 같은 기준으로 분류하여 집계 되고 있다.

\section{대륙별 유전자치료제 임상시험 승인 건수(1989-2017)}

대륙 별 임상시험 건수를 보면 총 2,597건 중 아메리카 대륙이 1,685 건(64.9\%)로 압도적인 다수를 차지한다. 그
다음으로 유럽이 602건(23.2\%), 아시아가 168 건(6.5\%), 호 주 34 건 $(1.3 \%)$, 아프리카가 6 건 $(0.2 \%)$ 을 차지하였다. 다 국적 임상시험은 102 건(3.9\%)이었다. 유전자치료는 $\mathrm{Big}$ Pharma가 많이 포진해 있는 북미대륙과 유럽에서 거의 대 다수의 임상시험이 이루어지고 있다.

\section{국가 별 유전자치료제 임상시험 승인 건수(1989-2017)}

임상시험 승인 건수를 국가별로 살펴보면 미국이 1,643 건(63.3\%), 영국이 221건(8.5\%)으로 절대적인 우위를 보 이고 독일이 92 건(3.5\%), 중국이 84 건(3.2\%)으로 뒤를 잇 고 있다. 그 다음으로는 프랑스 59건(2.3\%), 스위스 50건 $(1.9 \%)$, 일본 44건(1.7\%), 네덜란드 37건(1.4\%), 스페인 32 건( $(0.5 \%)$, 이탈리아 28 건(1.1\%), 캐나다 27 건 $(1.0 \%)$ 순이었 다. 한국은 20 건으로 $(0.8 \%) 14$ 위에 올라가 있다.

\section{질환 별 유전자치료제 임상시험 승인 건수(1989-2017)}

유전자치료제의 임상시험을 적응증 별로 살펴보면 종양 질환이 1,688 건으로 전체의 $65 \%$ 를 차지한다.

그 다음으로 단일유전자성 질환 287건(11.1\%), 감염성 질환 182 건(6.9\%), 심혈관계질환 180 건(6.9\%), 신경학적질 환 47 건(1.8\%) 순이다. 안질환에 34 건(1.3\%), 염증성질환 에 15 건 $(0.6 \%)$ 이 있으며, 기타 질환에 58 건( $2.2 \%)$ 의 임상 시험이 승인되었다(Table 1).

종양질환은 유전자치료 분야에서 임상연구가 가장 활발 하게 이루어지고 있는 분야이다. 난소암, 전립선암, 폐암, 유방암, 뇌종양 등 다양한 암에 임상시험이 진행 중이다. 암의 치료에는 바이러스성 벡터가 많이 사용되고 있으며 종양부위에 직접 주입하는 형태로 사용된다. 암세포를 제 어하기 위해서 cell suicide, cell death, growth inhibition, tumor suppression과 oncolysis 등의 기전을 사용한다.

유전질환으로는 래버씨선천성 흑암시, 낭포성섬유증, 지 단백지질분해효소 결핍, $\mathrm{ADA}$ 결핍장애, 혈우병 등에 대하 여 임상연구가 행해지고 있다. 유전자 운반체로는 $\mathrm{AAV}$, 레트로바이러스, 리포솜 등이 사용된다. 투여방법으로는 주로 혈관 주입으로 이루어지는데, 대상 조직인 안조직에 직접 주사하는 경우도 있었다. 단일 유전자성 질환의 경 우 결핍된 유전자 기능을 보충함으로써 기능의 복원을 기 대한다(Peters and Harris, 2018).

감염성질환의 임상연구는 $\mathrm{HIV}$, 간염 등에 대하여 이루 어지고 있다. 유전자전달체로는 레트로바이러스나 naked plasmid를 이용하며 정맥으로 투여된다. 작용기전은 면역 을 유도하는 면역치료와 관련이 있다. 
Table 1. Indications Addressed by Gene Therapy Clinical Trials (1989-2017)

\begin{tabular}{lcc}
\hline \hline \multirow{2}{*}{\multicolumn{1}{c}{ Indications }} & \multicolumn{2}{c}{ Gene therapy clinical trials } \\
\cline { 2 - 3 } & Number & \multicolumn{1}{c}{$\%$} \\
\hline Cancer diseases & 1,688 & 65.0 \\
Cardiovascular diseases & 180 & 6.9 \\
Gene marking & 50 & 1.9 \\
Healthy volunteers & 56 & 2.2 \\
Infectious diseases & 182 & 7.0 \\
Inflammatory diseases & 15 & 0.6 \\
Monogenic diseases & 287 & 11.1 \\
Neurological diseases & 47 & 1.8 \\
Ocular diseases & 34 & 1.3 \\
Others & 58 & 2.2 \\
\hline Total & 2,597 & 100.0 \\
\hline Souce:
\end{tabular}

Source: http://www.abedia.com/wiley/indications.php (updated Nov. 2017)

심혈관계질환의 경우에는 임상연구가 관상동맥질환, 말 초동맥질환, 심부전을 중심으로 이루어지고 있다. 유전자 운반체로는 naked plasmid가 가장 많고 바이러스성으로는 아데노바이러스가 주로 사용되는데 투여경로는 심장, 근 육, 혈관 등에 주사된다(Dunbar et al., 2018).

뇌신경계질환의 임상연구는 주로 파킨슨병, 알츠하이머, 당뇨병성 신경병증에서 이루어지고 있다. 사용되는 벡터 로는 $\mathrm{AAV}$, 렌티바이러스, 레트로바이러스, naked plasmid 등이 있다. 뇌신경계질환에서는 약리작용을 가지는 치료 단백질을 벡터가 발현, 분비하도록 하여 치료효과를 나타 내도록 한다. 질환에 따라 투여하는 방식이 달라서 알츠 하이머나 파킨슨병의 경우 뇌조직에 주사하고 당뇨병성 신경병증의 경우 근육에 주사한다(Lee, 2016; Hong et al., 2016; Abbasi, 2018; Saudemont et al., 2018; Tosoloni and Smith, 2018).

\section{벡터 별 유전자치료제 임상시험 승인 건수(1989-2017)}

임상시험 승인 건수를 유전자를 전달하는 벡터 별로 구 분해 보면 바이러스 벡터가 대다수를 차지하였다. 대표적 인 바이러스성 벡터로 adenovirus 521건(20.1\%), retrovirus 475건(18.3\%), adeno-associated virus 204건(7.9\%), lentivirus 196 건(7.5\%), vaccinia virus 127 건(4.9\%) 등이 사용되었다. 그 다음 빈도로는 herpes simplex virus 93건(3.6\%), pox virus 70 건(2.7\%), measles virus 13 건( $0.5 \%)$ 순서였다. Newcastle disease virus, Poliovirus, Semliki forest virus, Sendai virus, Simian virus, Venezuelan equine encephalitis virus replicon, Vesicular stomatitis virus 등도 소수의 임상시험에서 사용되 었다.

비바이러스성 벡터로는 유전자를 직접 전달하는 naked plasmid가 429건(16.5\%)으로 가장 많은 수를 차지하였다. RNA transfer도 48 건(1.8\%)이 사용되었고 siRNA 사용이 5 건( $0.2 \%)$, antisense oligonucleotide 사용이 6 건( $0.2 \%)$ 이 있 었다. 지질막으로 유전물질을 감싸서 식세포작용으로 유 전자를 전달하는 lipofection도 117 건(4.5\%)을 차지하였다. 그 외에 물리적인 방법을 이용하는 mRNA electroporation 이 6건(0.2\%) 있었다. Listeria monocytogenes, Streptococcus mutans, Vibrio cholerae, Shigella dysenteriae, Salmonella typhimurium 등과 같은 박테리아도 소수의 임상시험에 사용되 었다.

\section{유전자 타입 별 유전자치료제 임상시험 승인 건수(1989- 2017)}

유전자치료제 임상시험에서 전달된 유전자 타입은 적용 되는 질환에 따라 다른 만큼 종류가 다양하였다. Antigen이 498건(19.2\%), cytokine이 375건(14.4\%), receptor가 301건 $(11.6 \%)$ 으로 가장 많이 사용되었다. 그 다음으로는 결핍 유전자 221건(8.5\%), growth factor 183건(7.0\%), tumor suppressor 181 건(7.0\%), suicide gene 175 건(6.7\%), replication inhibitor 96건(3.7\%), marker 55건(2.1\%), oncolytic virus 52건 (2.0\%), transcription factor 35 건(1.3\%) 등이 사용되었다. 소 수의 경우에 antisense, cell cycle, hormone, oncogene regulator, porins, ion channels, transporters, ribozyme, siRNA 등이 사용 되었다.

\section{임상시험 단계 별 유전자치료제 승인 현황(1989-2017)}

임상시험 단계 별로 살펴보면 소수의 건강한 성인을 대 상으로 약물의 체내 흡수, 분포, 대사, 배설 등에 대한 자 료를 수집하면서 안전성을 평가하는 임상 제 1 상 단계에 있는 경우가 1,476 건으로 전체의 $56.8 \%$ 를 차지하였다. 소 규모의 환자를 상대로 적정용량의 범위(최적 투여량 등) 와 용법을 평가하는 임상 제 2 상 연구가 승인된 경우는 제 1 상과 제 3 상 혼재를 포함하여 $39 \%$ 를 차지하였다. 다음 단계로 대규모의 환자를 대상으로 약물의 유효성과 안전 성을 최종적으로 검증하는 임상 3상 단계에 도달한 경우 는 98 건으로 전체의 약 $4 \%$ 이었다. 지금까지 약물을 시판 한 후 부작용을 추적하여 안전성을 재고하는 임상 제 4 상 
Table 2. Phases of Gene Therapy Clinical Trials (1989-2017)

\begin{tabular}{lcc}
\hline \hline \multirow{2}{*}{ Phase } & \multicolumn{2}{c}{ Gene therapy clinical trials } \\
\cline { 2 - 3 } & Number & $\%$ \\
\hline Phase I & 1,476 & 56.8 \\
Phase I/II & 544 & 20.9 \\
Phase II & 445 & 17.1 \\
Phase II/III & 25 & 1.0 \\
Phase III & 98 & 3.8 \\
Phase IV & 3 & 0.1 \\
Single subject & 6 & 0.2 \\
\hline Total & 2,597 & 100.0 \\
\hline
\end{tabular}

Source: http://www.abedia.com/wiley/phases.php (updated Nov. 2017)

까지 승인된 경우는 3건이었다(Table 2).

\section{각국 보건당국의 유전자치료제 규제 가이드라인 현황}

각 나라마다 기술개발 수준과 연구기반, 바이오의약품 산업 수준, 의료 인프라 등의 여건에서 격차가 있는 만큼 유전자치료제 개발의 가이드라인도 국가 별로 서로 차이 를 보인다. 이에 더하여 유전자치료제가 다양한 방식으로 개발되고 있고 또한 관련기술이 빠른 속도로 발전해감에 따라서 먼저 만들어진 가이드라인은 시간이 지날수록 현 실을 규제하기에 무리가 따르게 된다. 이에 따라 각국의 규제당국은 학문의 진보를 반영하여 새로운 가이드라인을 제정 혹은 개정하고, 유전자치료제를 심사함에 있어서 유 연하고 합리적인 판단을 할 수 있도록 노력하고 있다. 각 국에서 제정된 유전자치료제 가이드라인은 품질관리, 제 조, 비임상시험, 임상시험, 시판 후 사후관리에 이르기까 지 전체적인 과정에 대한 규제와 관리의 틀을 제공한다 (Seo et al., 2015).

미국의 유전자치료제 가이드라인: 미국에서는 1998년 3월 에 처음으로 Guidance for Industry: Guidance for Human Somatic Cell Therapy and Gene Therapy가 나온 이래로 2018년 6월 현재까지 Cellular \& Gene Therapy Guidance와 관련하여 24 개의 guideline이 제정 혹은 개정되어 발간되 었다. 최근 3년 동안 세포 및 유전자치료와 관련된 9건 (2015년도 3건, 2016년도 1건, 2017년도 5건)의 새로운 guideline이 제정되어 공포되었다(Seo et al., 2015; US FDA homepage. Vaccines, Blood \& Biologics, Cellular \& Gene Therapy Guidance Documents, 2018). 이에 더하여 미국 FDA
는 유전자치료제의 허가를 원활하게 하기 위하여 유전자 치료제와 관련한 6 개의 새로운 가이드라인을 조만간 공포 할 예정이라고 한다(Terry, 2018).

유럽의 유전자치료제 가이드라인: 유럽에서는 European Medicines Agency (EMA)가 유전자치료제와 관련하여 2001 년에 Quality, preclinical and clinical aspects of gene therapy medicinal products를 처음으로 발간한 이래로 2018년 6월 현재까지 11 개의 guideline을 발간하였다. 이 가이드라인의 제정 취지는 유전자치료제 개발자들이 시판허가를 신청 하는 준비를 돕기 위한다고 천명되었다(Seo et al., 2015; European Medicines Agency homepage, Human regulatory, Scientific guidelines, Multidisplinary, Gene therapy, 2018).

우리나라의 유전자치료제 가이드라인: 우리나라 식품의 약품안전처에서도 유전자치료제 개발의 세계적인 흐름에 능동적으로 대처하고, 유전자치료제의 개발을 지원하기 위하여 아래와 같은 종류의 유전자치료제 가이드라인을 제정하여 시행하고 있다(Korean FDA homepage, 2018).

- 첨단바이오의약품 규제과학 상담 사례집-[민원인안내 서]. 2017-12-27

- 유전자치료제 비임상시험 평가 가이드라인-[민원인안 내서]. 2017-12-22

- 유전자치료제 임상시험 가이드라인-지연성 이상반응에 대비한 환자 추적관찰-[민원인 안내서]. 2016-10-31

- 임상시험용 유전자치료제의 특성분석, 제조 및 품질관 리 평가가이드-[민원인 안내서]. 2016-01-01

- 세포·유전자치료제 초기 임상시험 디자인 가이드라인 -[민원인 안내서]. 2015-11-30

- 신개념 첨단제제 민원검토를 위한 전문가 자문에 관한 절차-[공무원 지침서]. 2012-07-31

\section{결론 및 논의}

최근 몇 년 동안 미국과 유럽에서 여러 개의 유전자치 료제가 보건당국의 허가를 획득하였다. 유럽 $\mathrm{EMA}$ 에서 2012년 처음 유전자치료제로 승인된 글리베라는 지나치 게 높은 약가와 적은 환자 수로 인한 시장성 부족을 이 유로 유니큐어사는 아쉽게도 2017년 재등록을 포기하기 로 결정하였다(Warner, 2017). 그러나 글리베라는 서방선진 국에서 글로벌 수준의 첫 상용화된 제품으로서, 다른 후 속 유전자치료제 개발의 물고를 튼 것으로 큰 가치가 있 
었다. 2015년 이후에 미국과 유럽에서 연이어 승인된 다 수의 유망한 유전자치료제는 향후 유전자치료제 시대가 본격적으로 열릴 것을 예고하고 있다.

현재 국가 별로 보면 미국이 유전자치료제 연구를 가장 많이 진행하고 있다. 미국과 유럽이 유전자치료제 연구를 선도하고 있지만, 일부 유전자치료제 분야는 중국이 활발 하게 움직이고 있어서 향후에 중요한 역할을 할 것으로 생각된다(Seo et al., 2015).

그동안 우리나라도 많은 회사들이 유전자치료제 개발에 뛰어 들어 연구를 하고 있다. 2018년 5월 7일 Genetic and Biotechnology News에서 출시가 임박한 세계 유망 유전자 치료제 25종(25 Up and Coming Gene Therapies)을 선발하 였다. 여기에 우리나라 제품으로는 신라젠 펙사벡(PexaVec (Pexastimogene devacirepvec; JX-594))과 바이로메드의 $\mathrm{VM} 202$ 가 올라갔다.

신라젠의 펙사벡은 벡시니아 바이러스를 이용하여 직접 암세포를 용해시키고, 항암면역작용을 자극하는데 간세포 암종(Hepatocellular carcinoma) 치료제로 임상 3상 시험 중 이다. 펙사벡은 또 다른 4종의 항암제와 병용요법으로 전 이/진행성 고형암, 간세포암종, 신장암에 임상 $1 / 2$ 상 시험 중이다.

바이로메드의 VM202는 HGF728과 HGF 723을 발현하 는 naked plasmid 제제이다. VM202는 통증성 당뇨병성말 초신경병증(PDPN, painful diabetic peripheral neuropathy), 당 뇨병성 - 허혈성족부궤양(NHU, diabetic foot ulcers), 중증하 지허혈(CLI, critical limb ischemia)을 대상으로 임상 3상, 허 혈성심장질환(IHD, ischemic heart disease)과 루게릭병(근위 축성축삭경화증, $\mathrm{ALS}$, amyotrophic lateral sclerosis)을 대상 으로 임상 2상 시험을 진행하고 있다(Philippidis, 2018). 그 외에도 전임상과 임상 1,2 상 단계에 있는 국내 개발 유 전자치료제가 많이 포진하고 있어서 전도가 밝다.

미국 국립보건연구원(NIH) 산하 US National Library of Medicine에서 운영하는 ClinicalTrial.gov 사이트에 의하면 2018년 6월 현재 'gene therapy'로 검색 시 나타나는 유전자 치료 관련 임상연구는 494건이며, 임상 3상 시험이 진행 되고 있는 pipeline이 27개로 나타난다. 유전자치료제 연 구의 초기에는 난치암이나 희귀 유전질환이 주요 표적이 었는데 이제 적용 타겟이 암, 유전질환, 만성질환, 감염질 환, 심혈관계, 신경계질환, 만성질환 등으로 다양해지고 있다(ClinicalTrial.gov homepage, 2018).

유전자치료제의 적용대상은 암이 가장 많은 연구되고 있으며 그 다음으로 단일 유전자질환이다. 단일 유전자질
환은 작용기전이 비교적 단순하고 대부분 희귀질환으로 지정되어 있어서 허가 시 희귀질환의약품으로 지정될 수 있어서 세제혜택과 일정기간 독점판매권 확보가 용이한 것이 개발사들에게 유리하게 작용한다. 그리고 또 다른 중 요한 대상은 환자의 폭이 넓어 수요가 큰 심혈관계질환이 다. 환자 수와 시장규모를 생각하면 이 분야에서도 blockbuster 급의 유전자치료제 신약이 등장하리라 예상된다.

2018년 6월 4일에서 7일 사이에 미국 보스턴에서 개최 된 $2018 \mathrm{BIO}$ International Convention (BioUSA)에서 유전자 치료제 개발은 정밀의학과 더불어 관심의 중심이었다. Dr. Scott Gottlieb 미국 FDA 국장은 토론회에서 2022년까지 미국에서 약 40 개 정도의 유전자치료제가 승인될 것으로 전망되며, 10 년 이내에 낫적혈구빈혈증과 같은 유전질환은 치료법을 찾게 될 것이라고 언급하였다. 또한 유전자치료 제의 특수성을 감안하여 앞으로 허가과정에 이전과 다르 게 접근할 것이며, 허가과정을 원활하게 하기 위하여 유 전자치료제와 관련한 6 개의 새로운 가이드라인을 조만간 공포할 것이라고 하였다(Terry, 2018). 이는 미국 정부가 유 전자치료제의 잠재력을 높이 평가하고 허가를 전향적으로 검토하고 있음을 시사한다.

이와 같은 미국 $\mathrm{FDA}$ 의 움직임은 2018년 6월 27일 서울 에서 열린 글로벌 바이오 컨퍼런스(GBC 2018)에서 미국 식품의약국(FDA) 생물학적제제 평가연구 센터(CBER) 조 직첨단치료제국(OTAT) 윌슨 브라이언(Wilson W. Bryan) 박 사의 기조연설로 다시 한 번 확인되었다. 그는 "유전자치 료제는 심각한 질환을 치료하고 환자들의 삶을 바꾸는 만 큼 개발과 허가과정에서도 시각을 바꿀 필요가 있다. 첫 임상시험을 설계할 때 한 번으로 안전성과 유효성 근거를 수집해 바로 시판까지 할 수 있도록 하는 방법을 고려해 야 하며, 유전자치료제는 강력한 과학적 근거를 바탕으로 하는 만큼 유효성 근거를 제공한다면 임상 1상만으로도 승인 가능하도록 초기부터 임상의를 참여시키고 유효성 데이터 확보하고 제조 문제도 미리 대비해야 할 필요하 다"고 조언했다. 그는 "미국 $\mathrm{FDA}$ 는 세포치료제, 유전자치 료제 등 첨단 재생의약품이 환자들에게 가능한 빨리 제공 되도록 규제 철폐와 함께 안전성을 강화하는 정책을 추진 하고 있다"고 말했다. 또한 "유전자치료제는 향후 아주 많은 환자들의 삶을 바꿔 놓을 혁신적 치료제가 될 것"이 라는 전망을 내놓았다(Park, 2018).

이와 같이, 여러 개의 유전자치료제가 잇달아 성공적으 로 승인되면서, 세계의 유전자치료제의 개발과 허가 여건 이 매우 긍정적으로 변화해 가고 있다. 유전자치료제 연 
구 개발의 앞을 막고 있는 여러 가지 기술적, 제도적인 난 관도 하나씩 사라져가고 있다. 다양한 유전자치료가 개발 되어서 인류에게 큰 고통을 주고 있는 암이나 유전질환, 감염질환, 성인병과 같은 여러 가지 난치병에서 생명을 구 하는 희망이 되어 주기를 기대한다.

\section{ACKNOWLEDGMENTS}

None.

\section{CONFLICT OF INTEREST}

No conflict of interests exists for any of the authors.

\section{REFERENCES}

Abbasi J. Biotech Innovations. Clinical Advances in Human Gene Therapies. JAMA. 2018. 319: 113.

Ameri H. Prospect of retinal gene therapy following commercialization of voretigene neparvovec-rzyl for retinal dystrophy mediated by RPE65 mutation. J Curr Ophthalmol. 2018. 30: $1-2$.

Blaese RM, Culver KW, Miller AD, Carter CS, Fleisher T, Clerici

M, Shearer G, Chang L, Chiang Y, Tolstoshev P, Greenblatt JJ, Rosenberg SA, Klein H, Berger M, Mullen CA, Ramsey WJ, Muul L, Morgan RA, Anderson WF. T lymphocyte-directed gene therapy for ADA- SCID: initial trial results after 4 years. Science. 1995. 270: 475-480.

Choi JW. What is virus to cancer? Two strategies to treat cancers. Opinion. Biospectator. 18 Jul 2017.

ClinicalTrials.gov homepage (ClinicalTrials.gov is a database of privately and publicly funded clinical studies conducted around the world.). retrieved on 27 Jun 2018. https://www.clinicaltrials.gov/ct2/results?term $=$ cancer\&cond $=$ gene + therapy \&strd $\mathrm{s}=01 \% 2 \mathrm{~F} 01 \% 2 \mathrm{~F} 2010 \&$ strd_e $=06 \% 2 \mathrm{~F} 25 \% 2 \mathrm{~F} 2017 \&$ age $\mathrm{v}=\&$ gndr $=\&$ type $=\& \mathrm{rslt}=\&$ phase $=1 \&$ Search $=$ Apply

Conry RM, Westbrook B, McKee S, Norwood TG. Talimogene laherparepvec: First in class oncolytic virotherapy. Hum Vaccin Immunother. 2018. 14: 839-846.

Dunbar CE, High KA, Joung JK, Kohn DB, Ozawa K, Sadelain M. Gene therapy comes of age. Science. 2018. 359: 1-10.

European Medicines Agency homepage. Human regulatory, Scientific guidelines, multidisplinary, Gene therapy. retrieved on 27 Jun 2018. http://www.ema.europa.eu/ema/index.jsp?curl=pages/regulation/general/general content 000410.jsp\&mid= WC0b01ac058002958d
Friedmann T, Roblin R. "Gene therapy for human genetic disease?". Science. 1972. 175: 949-955.

Gene Therapy Clinicla Trials Worldwide homepage. The Journal of Gene Medicine. updated Nov. 2017. retrieved on 27 Jun 2018. http://www.abedia.com/wiley/index.html

Hong SW, Seo SK, Ryu SY, Uhm JH, Kim SH, Baek JH, Kim H, Lee BY, Moon KS, Park KL, Oh YK, Choi BH, Kim JY, Clinical research trend in gene therapy. Dept of Advanced Bio product, National Institute of Food and Drug Safety Evaluation. 31 May 2016.

Korean FDA homepage. Legal Data. Legal Information. Guide line for Officers. Guideline for Civil Petitioners. Gene Therapy. http://www.mfds.go.kr/ index.do. retrieved on 27 Jun 2018.

Lee TG. Latest trend of gene therapy. Home page of Korean Drug Development Fund. Trend of new drug development $>$ Archive $>$ Trend of new drug development. Expert Opinion. 6 Feb 2017a.

Lee HK. Norvatis, The first US FDA-approved CAR-T, Kymriah. The start of new paradigm in the approval of new medicine to treat acute leukemia. Medical News. 31 Aug 2017b.

Lee HK. US FDA, Approval of Luxturna, treatment for acute genetic retina diseases, Single dose gene therapy, scheduled to launch next year. Medical News. 20 Dec 2017c.

Lee HM. Methods and research trend of gene therapy. BRIC View. 2016. T22: 1-17.

Liu Y, Chen X, Han W, Zhang Y. Tisagenlecleucel, an approved anti-CD19 chimeric antigen receptor T-cell therapy for the treatment of leukemia. Drugs Today (Barc). 2017. 53: 597-608.

Park DY. Dr. Bryan of US FDA said "Gene therapy development, Try to hit a homer" MediGate News. 28 Jun 2018.

Paton DM. Nusinersen: antisense oligonucleotide to increase SMN protein production in spinal muscular atrophy. Drugs Today (Barc). 2017. 53: 327-337.

Pawliuk R, Westerman KA, Fabry ME, Payen E, Tighe R, Bouhassira EE, Acharya SA, Ellis J, London IM, Eaves CJ, Humphries RK, Beuzard Y, Nagel RL, Leboulch P. Correction of sickle cell disease in transgenic mouse models by gene therapy. Science. 2001. 294: 2368-2371.

Peters R, Harris T. Advances and innovations in haemophilia treatment, Reviews. Nature Reviews Drug Discovery. 2018. 17: 493-508.

Philippidis A. 25 Up and Coming Gene Therapies. The Lists, Investment, Incentives, and IP Drive Growth in Clinical Development. Genetic and Biotechnology News. 07 May, 2018.

PubMed homepage. retrieved on 27 June 2018. www.ncbi.nlm.- 
nih.gov/pubmed

Roberts ZJ, Better M, Bot A, Roberts MR, Ribas A. Axicabtagene ciloleucel, a first-in-class CAR $\mathrm{T}$ cell therapy for aggressive NHL. Leuk Lymphoma. 2017. 23: 1-12.

Saudemont A, Jespers L, Clay T. Current Status of Gene Engineering Cell Therapeutics. Front Immunol. 2018. 9: 153.

Scott LJ. Alipogene tiparvovec: a review of its use in adults with familial lipoprotein lipase deficiency. Drugs. 2015. 75: 175-182.

Seo KW, Seo SK, Ruy SL, Uhm JH, Lee BY, Kim BC, Baek JH, Kim H, Oh YK, Choi BH, Kim JY, Park KL, Moon KS. Trend of $R \& D$ and regulation of gene therapy. Dept of Advanced Bio product, National Institute of Food and Drug Safety Evaluation. 30 Dec 2015.

Spinraza home page. retrieved on 27 June 2018. https://www.spinraza.com/.

Stirnadel-Farrant H, Kudari M, Garman N, Imrie J, Chopra B, Giannelli S, Gabaldo M, Corti A, Zancan S, Aiuti A, Cicalese MP, Batta R, Appleby J, Davinelli M, Ng P. Gene therapy in rare diseases: the benefits and challenges of developing a patient-centric registry for Strimvelis in ADA-SCID. Orphanet J Rare Dis. 2018. 13: 49.

Terry M. Gottlieb at BIO 2018: 40 Gene Therapy Approvals by 2022. Biospace. 07 Jun, 2018.
Tosolini AP, Smith GM. Editorial: Gene Therapy for the Central and Peripheral Nervous System. Front Mol Neurosci. 2018. 11: article 54.

Trojan J, Johnson TR, Rudin SD, Ilan J, Tykocinski ML, Ilan J. "Treatment and prevention of rat glioblastoma by immunogenic C6 cells expressing antisense insulin-like growth factor I RNA". Science. 1993. 259: 94-97.

US FDA homepage. Vaccines, Blood \& Biologics, Cellular \& Gene Therapy Guidance Documents. retrieved on 27 Jun 2018. https://www.fda.gov/BiologicsBloodVaccines/GuidanceComplianceRegulatoryInformation/Guidances/Cellularand GeneTherapy/default.htm

Warner E. Goodbye Glybera! The World's First Gene Therapy will be Withdrawn. Labbiotech.eu. 20/04/2017. retrieved on 27 Jun 2018. https://labiotech.eu/uniqure-glybera-marketingwithdrawn/

https://doi.org/10.15616/BSL.2018.24.3.157

Cite this article as: Kwon SI. Current Status of the Clinical Development of Gene Therapy. Biomedical Science Letters. 2018. 24: 157-167. 